\section{THE SANITARY EXAMINATION OF WATER SUPPLIES.}

$A$ A extremely valuable and interesting report' has $A$ been issued by the sanitary authorities of the City of Chicago on the results of the chemical and bacteriological examinations of the waters between Lake Michigan at Chicago and the Mississippi River at St. Louis for the purpose of determining their condition and quality before and after the opening of the Sanitary Canal. For the diversion from Lake Michigan of the sewage of Chicago and its inoffensive disposal towards the Mexican Gulf, a canal was cut to carry the sewage, much diluted with lake water, into the Illinois River, a distance of $2 y$ miles. From this point the Illinois River, after a course of 289 miles, discharges into the Mississippi at Grafton, which is about 38 miles above St. Louis. The investigations originated from the fact that the State of Missouri and the City of St. Louis had applied for a Federal injunction against the further operation and development of the Sanitary Canal of the Chicago Sanitary District on the ground that the purity of the water supply of St. Louis was endangered thereby. Chicago replied by instituting a commission to examine into the condition of the waters between Chicago and St. L Lowis, a distance of 356 miles.

The Chicago Municipal Laboratory (Dr. Gehrmann), the Liniversity of Chicago (Prof. Jordan), and the University of Illinois (Profs. Palmer and Burrill) collaborated in the work, a common plan of operation was devised, a uniform scheme for the bacteriological and chemical examinations agreed upon, and forty stations were fixed for taking the samples, of which forty were collected weekly and delivered to each of the three laboratories. The work extended over a period of about thirteen months, and during that time some 8600 samples were examined. The investigations show that considerable self-purification has taken place before the Sanitary Canal discharges its sewage into the Illinois (29 miles), and that this continues until, before Averyville (159 miles) is reached, all trace of sewage pollution has disappeared from the waters of the Illinois. Since there. is still another 188 miles to be traversed before any pollution could reach St. Louis, the possibility of Chicago's sewage endangering the purity of St. Louis's water must be dismissed as impossible. In all probability such an exhaustive series of observations over so extended a stretch of water for so long a period has never before been attempted, and the results obtained are of considerable general interest. A valuable feature of the report is the detailed description of the methods employed for both the chemical and bacteriological portions of the examinations. The report illustrates the proper manner in which a great question, such as it deals with, should be approached and a solution be sought for, and we commend its perusal to hygienic authorities in this country.

R. T. HEWLFTT.

\section{NOTES.}

THE British Rainfall Organisation, founded in 1860 by the late Mr. G. J. Symons, F.R.S., will henceforth be carried on under the sole charge of Dr. H. R. Mill, Mr. Sowerby Wallis having been compelled by ill-health to retire after more than thirty years' connection with the ussociation.

THE summer meeting of the Iron and Steel Institute. was opened on Tuesday last at Barrow-in-Furness under the

1 "Report of Streams Examination." Made under the Direction of Arthur R. Reynoldi, M.D., Commissirner of Heath, City of Chicago. December, rgoz.

$$
\text { NO. } 1765 \text {. vOL. 68] }
$$

chairmanship of Mr. Andrew Carnegie, the president of the institute.

TuE whaler Terra Nova, which has been acquired by the Government and fitted out as a relief ship for the Discovery, left Portland on Wednesday of last week for Hobart, Tasmania, where, as has been mentioned in a former issue, she will be joined by the Morning. In order that she may reach her destination as rapidly as possible, she will be towed as far as Aden by one of His Majesty's ships; from Aden she will have to depend on her own resources of steam and sait. It is, however, anticipated that the two ships, the Morning and Terra Nova, will be able to leave Hobart in order to make their way south through the Antarctic ice in search of the Discovery by December I.

According to a Reuter telegram from Brest, the steamer Frantrais, with the members of the Charcot expedition, which is proceeding towards the South Pole in search of Dr. Otto Nordenskjold, ieft that place on Sunday afternoon last.

THE German South Polar Expedition has arrived safely at St. Helena.

A telegram from Naples on August 26 through Reuter's Agency stated that on that day a crater of Vesuvius which had been quiet since 1895 opened, and a great flood of lava poured forth.

A rel.fGRA from Wellington, New Zealand, states that an eruption of the Waimangu geyser took place on Saturday last, causing the loss of four lives.

Accorving to a telegram from New York a gold seeker has just arrived at Vancouver after an absence of four years, during which time he has been exploring the Mackenzie River district in the direction of the Arctic circle, and has brought with him what purports to be a piece of silk which formed part of the balloon of the ill-fated André.

We regret to have to announce the death at Marstrand, Sweden, at the age of sixty years, of Prof. W. H. Corfield, sanitary adviser to H.M. Office of Works, and author of numerous works relating to hygiene.

A MoNtMext to the French chemist Laurent was recently unveiled by the French Minister of Agriculture at Langres (Haute-Marne).

THe British Medical Journal states that Dr. Stiles, who, it is said, has discovered a parasite which he believes to be effective in destroying mosquitoes, is about to put the efficacy of the destroyer to the test at Cape May or some other place in New Jersey where mosquitoes are prevalent. The investigation is undertaken at the request of Prof. Smith, State Entomologist of New Jersey, who has helped Dr. Stiles in his search for a parasite suitable for the purpose.

A RECTER telegram from Lagos states that the Legislative Council has passed a law' making it a penal offence to introduce wireless telegraphy into the colony without the sanction of the Governor in Council.

Accordivg to a telegram received through Laffan's Agency, Mr. Marconi, on his arrival at New York by the Lucania, stated that the vessel was never out of communication with either Great Britain or America on any day during the voyage. On Tuesday night of last week a nessage was received from Poldhu, when the Lucania was in mid-ocean, giving the result of that day's yacht race. The Nantucket station gave the result of Thursday's race. Mr. 